\title{
Extensive permethrin and DDT resistance in Anopheles arabiensis from eastern and central Sudan
}

\author{
Yousif E Himeidan ${ }^{1 *}$, Muzamil M Abdel Hamid², Christopher M Jones ${ }^{3}$ and Hilary Ranson ${ }^{3}$
}

\begin{abstract}
Background: The distribution of insecticide treated nets (ITN) has been dramatically scaled up in eastern and central Sudan. Resistance to insecticides has already been reported in this region and there is an urgent need to develop appropriate resistance management strategies, which requires detailed information on the extent and causes of resistance. This study assessed resistance to permethrin and DDT in seven populations of Anopheles arabiensis from Sudan.

Results: Three out of the seven populations were defined as resistant to permethrin and five of six populations resistant to DDT according to WHO criteria. The $1014 \mathrm{~F} \mathrm{kdr} \mathrm{allele} \mathrm{was} \mathrm{present} \mathrm{in} \mathrm{all} \mathrm{six} \mathrm{populations} \mathrm{tested} \mathrm{and} \mathrm{the}$ presence of this allele was significantly correlated with resistance to permethrin $(P=0.0460)$. While homozygous $1014 \mathrm{~F}$ individuals were statistically not more likely to survive (53.7\%) permethrin than to be killed (38.6\%) by the diagnostic dose, there was no difference in the likelihood of permethrin survival in heterozygotes $(P=0.7973)$. The susceptible genotypes were more likely to be killed by permethrin exposure than to survive $(P=0.0460)$. The $1014 \mathrm{~F}$ allele failed to confer a survival advantage to the WHO diagnostic dose of DDT in either the homozygous or heterozygous state. The $1014 \mathrm{~S}$ allele was not detected in any of the populations tested.

Conclusion: The kdr allele is certainly contributing to the extensive resistance to permethrin and DDT in Sudan but the high number of DDT (43\%) and permethrin (16.7\%) survivors that did not contain either kdr alleles suggests that other resistance mechanisms are also present in these populations. The high frequency of permethrin resistance throughout central and eastern Sudan is a cause of great concern for malaria control activities.
\end{abstract}

\section{Background}

Ongoing strategies of malaria vector control rely greatly on the use of indoor residual spraying (IRS) and insecticide-treated nets (ITNs). The current success of these strategies in reducing malaria contributed towards the optimism that elimination of this disease as a public health problem is a feasible objective [1]. Substantial international efforts have been made during the last three years enabling access to approximately 289 million ITNs in sub-Saharan Africa, enough to cover $76 \%$ of the 765 million people at risk of malaria. The number of countries that employed IRS as vector control strategy

\footnotetext{
* Correspondence: yosifhimeidan@hotmail.com

'Entomology Unit, Faculty of Agriculture and Natural Resources, University of Kassala, New Halfa, Sudan

Full list of author information is available at the end of the article
}

increased from 31 in 2007 to 68 in 2009 [2]. Further scale- up of IRS and ITNs is occurring throughout the African continent.

ITNs and, to a large extent, IRS are highly dependent on pyrethroid insecticides. The widespread use of this class of insecticide increases the risk of resistance. The situation may be accelerated by the reintroduction of DDT in several countries in Africa as cross-resistance between these insecticide classes can occur as a result of amino acid substitutions in the shared target site. All major malaria vectors in Africa have developed resistance to these insecticides and the resistance alleles appear to be spreading at an exceptionally rapid rate [3].

Pyrethroids and DDT target the voltage-gated sodium channel site. Two alternative substitutions of the leucine 1014 residue can lead to target site resistance. The

\section{Biomed Central}


1014F allele was first identified in strains of An. gambiae from Burkina Faso and Côte d'Ivoire [4] and the 1014S allele was later identified in this species in Kenya [5]. Both alleles are now widely distributed in An. gambiae [3]. In An. arabiensis, 1014F has been found in several widely dispersed populations from Burkina Faso [6,7], Tanzania [8], Sudan [9,10], Senegal [11] and Ethiopia $[12,13]$. The $1014 \mathrm{~S}$ allele was also observed in wild populations of An. arabiensis from Uganda [14] and western Kenya [15,16]. Both 1014F and $1014 \mathrm{~S}$ alleles have been detected together in the same populations in Sudan [9] and Cameroon [17].

In Sudan, our surveys in 2005 showed that the frequency of the $1014 \mathrm{~F}$ allele in An. arabiensis was more than double in areas where insecticide-treated nets were used compared to a cotton growing area which was regularly treated with insecticides [9]. The result suggested that pyrethroid-based vector control may extend and increase $\mathrm{kdr}$ distribution. The distribution of ITNs in Sudan has been scaled up dramatically in recent years and 60\% ITN coverage rate has been achieved (National Malaria Control Programme, unpublished data). There is therefore an urgent need to monitor the distribution of resistance and to develop appropriate resistance management strategies. The data presented will further assist in this process.

\section{Methods}

\section{Study sites}

The study was carried out in five states of eastern and central Sudan. The states surveyed were Sennar [sites surveyed were Sennar town $\left(33^{\circ} 55^{\prime} \mathrm{E}, 13^{\circ} 10^{\prime} \mathrm{N}\right), \mathrm{Al}$ Boster $\left(33^{\circ} 36^{\prime} \mathrm{E}, 13^{\circ} 32^{\prime} \mathrm{N}\right)$ and Mayirno $\left(33^{\circ} 66^{\prime} \mathrm{E}, 13^{\circ}\right.$ $\left.47^{\prime} \mathrm{N}\right)$ ], Blue Nile [site surveyed were Damazine town $\left(34^{\circ} .35^{\prime} \mathrm{E}, 11^{\circ} .82^{\prime} \mathrm{N}\right)$, Guneess $\left(34^{\circ} 40^{\prime} \mathrm{E}, 11^{\circ} 80^{\circ} \mathrm{N}\right)$ and Al Rosseires ( $\left.34^{\circ} 38^{\prime} \mathrm{E}, 11^{\circ} 80^{\prime} \mathrm{N}\right)$ ], White Nile [site surveyed were Kosti $\left(32^{\circ} .67^{\prime} \mathrm{E}, 13^{\circ} .14^{\prime} \mathrm{N}\right)$, Rabak (32 $.70^{\prime} \mathrm{E}$, $\left.13^{\circ} .13^{\prime} \mathrm{N}\right)$ and Asalaya $\left(32^{\circ} .73^{\prime} \mathrm{E}, 13^{\circ} .25^{\prime} \mathrm{N}\right)$ ], Khartoum [site surveyed were Al Rimeilah $\left(32^{\circ} 31^{\prime} \mathrm{E}, 15^{\circ} 33^{\prime} \mathrm{N}\right)$ and $\mathrm{Al} \mathrm{Kalaklah}\left(32^{\circ} 30^{\prime} \mathrm{E}, 15^{\circ} 32^{\prime} \mathrm{N}\right)$ ] and Gadaref state [sites surveyed were Gadaref town ( $\left.34^{\circ} 16^{\prime} \mathrm{E}, 14^{\circ} 04^{\prime} \mathrm{N}\right)$, $\mathrm{Al} \mathrm{Faw}\left(35^{\circ} 38^{\prime} \mathrm{E}, 14^{\circ} 19^{\prime} \mathrm{N}\right)$ and Al Shuwak (35 85' E, $14^{\circ} 42^{\prime} \mathrm{N}$ )] (Figure 1). Because the distance between the sites surveyed within the states is shorter (less than 10 $\mathrm{km}$ ), each state was treated as one population except Sennar and Gadaref where Mayirno, Al Faw and Al Shuwak were considered different populations due to the relatively long distances (i.e. the distance between $\mathrm{Al}$ Faw and $\mathrm{Al}$ Shuwak is more than $180 \mathrm{~km}$ ) which separate them (Figure 1). These states represent the major malaria endemic areas in eastern and central Sudan. The ITN coverage achieved in 2010 was $94 \%, 87 \%, 80 \%$, $77 \%$ and $52 \%$ in Sennar, Blue Nile, Gadaref, White Nile and Khartoum states, respectively (National Malaria
Control Programme, unpublished data). There is no routine IRS programme in these regions although IRS with pyrethroids (e.g. Deltamethrin) is occasionally applied in the rainy season (July - October). DDT has not been used for IRS since 1996 when the last round was done in a remote area.

\section{Mosquito collections}

Anopheles larvae were collected based on cross sectional surveys from their natural breeding sites such as animal hoof prints, leakage of pipes, ponds and puddles during July - November 2009. To reduce in-breeding bias, larvae were sampled from more than one (usually at least three) breeding sites. In some states, e.g. Sennar and White Nile, the larvae were collected on two separate occasions over a period of two weeks. The mosquitoes were reared to adulthood, in field insectaries in the major towns of each state and identified using morphological keys [18]. Based on the results from the previous studies in central and eastern Sudan, all insects were treated as An. arabiensis as this vector was the only member of the An. gambiae complex found in the region $[9,10,19,20]$.

\section{Insecticide susceptibility tests}

Insecticide susceptibility tests were carried out using the standard WHO protocol [21]. Two to three day-old non blood-fed adult female $A n$. arabiensis were tested. Batches of 20-25 mosquitoes were exposed to test papers impregnated with $0.75 \%$ permethrin or $4 \%$ DDT. Controls included batches of mosquitoes from each site exposed to untreated papers. The knockdown effect of each insecticide was recorded every 10 minutes over the one-hour exposure period. Mosquitoes were then transferred to a recovery tube and provided with $10 \%$ sugar solution. Final mortality was recorded 24 hours postexposure.

\section{Mosquito DNA preparation and kdr genotyping}

DNA from a single female mosquito was extracted using the Livak method [22] and resuspended in 50- $\mu \mathrm{L}$ of $\mathrm{dd}_{2} \mathrm{O}$. The purity and concentration of DNA were measured using Nanodrop spectrophotometer (Nanodrop ND-1000 Technologies).

Populations from Damazin, Kosti, Sennar and Mayirno were genotyped at the Liverpool School of Tropical Medicine (LSTM) using the Taqman probe described by Bass et al. [23]. A small number of samples from Khartoum and Al Shuwak were sequenced.

\section{Data analysis}

Data were analysed using descriptive and inferential statistics. Fifty and ninety five percent knockdown times $\left(\mathrm{KDT}_{50}\right.$ and $\left.\mathrm{KDT}_{90}\right)$ were computed using survival 


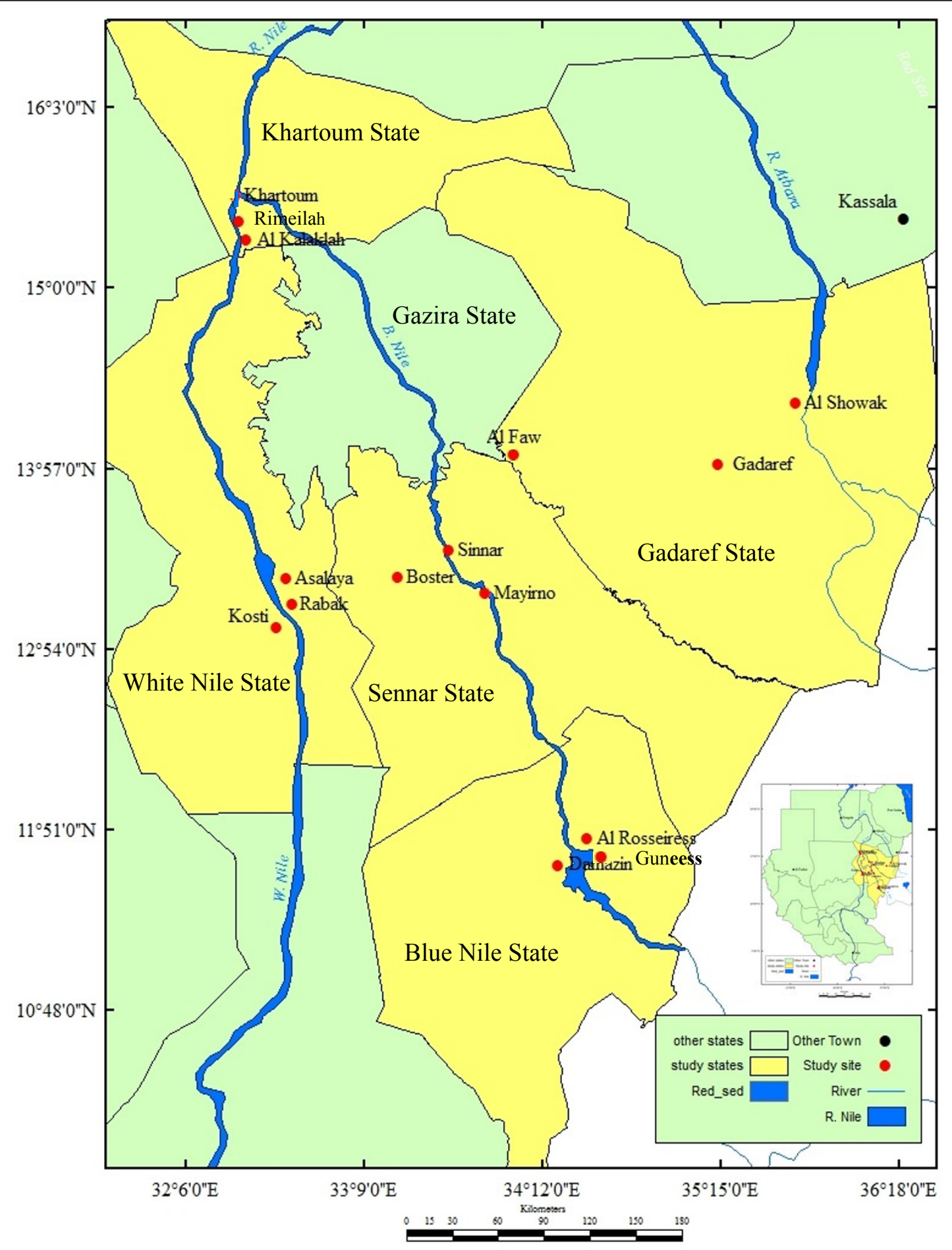

Figure 1 Map showing the study sites in Central and Eastern Sudan.

probit analysis (AnalystSoft Inc., BioStat v2009). TukeyKramer HSD tests were used to determine the difference in the means of mosquito mortality rates between the populations for each insecticide treatment. Chi-square tests were used to compare the frequencies of $\mathrm{kdr}$ alleles between the two phenotypes of surviving and dead mosquitoes for each insecticide. The association between the presence (yes/no) of kdr genotype and resistance phenotype (resistance/susceptible) was further confirmed for both insecticides using nominal logistic 
regression model. This analysis was conducted using JMP statistical software (JMP SAS Institute Inc. 2003).

\section{Results \\ Mortality rates}

The mortalities at 24 hours post-exposure are shown in Table 1 and 2. Based on WHO criteria, all populations would be defined as resistant or 'potentially resistant' to permethrin and DDT. A high frequency of peremthrin resistant individuals was found in Kosti (60\% mortality), Sennar (61\% mortality;) and Damazin (77\% mortality). These same three populations, in addition to Mayirno and $\mathrm{Al}$ Shuwak populations, showed less than $80 \%$ mortality to DDT and are thus defined as resistant (Table 2 ). The population from Khartoum demonstrated potential resistance to DDT (94.5\% mortality (Table 2).

\section{Knockdown effect}

The $50 \%$ and $90 \%$ knockdown time thresholds $\left(\mathrm{KDT}_{50}\right.$ and $\mathrm{KDT}_{90}$ ) determined over a one-hour period against permethrin and DDT are shown in Table 1 and 2. All populations, with the exception of Khartoum, had similar KDT50s for permethrin. The Khartoum population was knocked down significantly faster with permethrin. Similarly, the Khartoum population had a significantly lower KDT50 with DDT than the other populations. For DDT, the Kosti population took significantly longer to be knocked down than any other population.

\section{Knockdown resistance (kdr) alleles}

Table 3 summarises the presence of $1014 \mathrm{~F}-\mathrm{kdr}$ allele in six populations of An. arabiensis. The data are stratified according to whether they survived or died after exposure to the WHO diagnostic dose of permethrin and DDT. Of 248 mosquito specimens screened for both $\mathrm{kdr}$ alleles, the 1014F-kdr allele was present in 165 (96 alive and 69 dead) specimens. The 1014S-kdr allele was not detected in any genotyped mosquito specimens. Data from all sites were pooled by insecticide and the correlation between genotype and phenotype was determined. Homozygous 1014F individuals were not more likely to survive (53.7\%) permethrin exposure than to be killed $(38.6 \%)$ by the diagnostic dose $(\chi 2=2.222, P=0.1361)$. There was no difference in likelihood of permethrin survival in heterozygotes $(\chi 2=0.066$, d.f. $=1, P=0.7973)$. The susceptible genotypes were more likely to be killed by permethrin exposure than to survive $(\chi 2=3.981, P=$ $0.0460)$ (Table 4). However, $16.7 \%(9 / 54)$ of the permethrin survivors were 1014L homozygotes. The 1014F allele failed to confer a survival advantage to the WHO diagnostic dose of DDT in either the homozygous or heterozygous state. Surprisingly, the heterozygous 1014F individuals were significantly $(41.7 \%)$ more likely to be killed by DDT than to survive (24.4\%) by the diagnostic dose $\left(\chi^{2}=4.913, P=0.0267\right)$. Similarly there was no increased risk of DDT-induced death for the $1014 \mathrm{~L}$ genotype $(\chi 2=1.521, P=0.2174)$ and indeed approximately half $(43 \%)$ the DDT survivors lacked any $\mathrm{kdr}$ allele (Table 4). Overall, unlike DDT insecticide $(\chi 2=$ $1.521, P=0.2174)$, the nominal logistic regression confirmed a significant association between the present (yes/no) of kdr mutation (L1014F) and permethrin resistance phenotype (resistance/susceptible) $(\chi 2=3.981, P$ $=0.0460$ ). This could be further supported by the interesting fact that the highest $1014 \mathrm{~F}$ frequency was observed in the most ever resistant population to permethrin from Kosti (Table $1 \& 3$ ).

\section{Discussion}

Based on the WHO criteria for characterizing insecticide resistance/susceptibility, no evidence for full susceptibility to permethrin or DDT was found among the populations tested. The populations of An. arabiensis from Kosti, Sennar and Damazin were resistant to both permethrin and DDT. In addition, resistance to DDT was demonstrated in Mayirno and $\mathrm{Al}$ Shuwak. The KDT $\mathrm{T}_{50}$ and $\mathrm{KDT}_{90}$ for DDT in the current study was much higher than those reported for a completely susceptible population from New Halfa, eastern Sudan [9]. DDT was banned in Sudan for agricultural use in 1980 but continued to be used in vector control for a further 15 years. Hence the high level of DDT resistance may be a

Table 1 Mean mortalities and $50 \%$ and $\mathbf{9 0 \%}$ knockdown times (in minutes) $\left(\mathrm{KDT}_{50}\right.$ and $\mathrm{KDT}_{\mathbf{9 0}}$ ) of female Anopheles arabiensis in populations from eastern and central Sudan following exposure to permethrin.

\begin{tabular}{|c|c|c|c|c|}
\hline Population & No. & Mortalities \% (95\% Cl) & $\mathrm{KDT}_{50}(95 \% \mathrm{Cl})$ & $\mathrm{KDT}_{90}(95 \% \mathrm{Cl})$ \\
\hline Sennar & 300 & $61.3(44.4-78.3) b c$ & $31.9(30.2-33.7)$ & $105.1(91.4-118.8)$ \\
\hline Mayirno & 100 & $81.0(79.8-82.2){ }^{a b c}$ & $25.3(18.4-32.2)$ & $59.7(52.7-66.6)$ \\
\hline Damazin & 300 & $77.3(60.4-94.3){ }^{a b c}$ & $37.4(29.6-43.6)$ & $51.6(30.3-72.8)$ \\
\hline Khartoum & 175 & $97.5(96.3-98.7)^{a}$ & $19.8(18.2-21.2)$ & $33.9(32.1-36.2)$ \\
\hline Kosti & 300 & $60.0(43.1-77.0)^{c}$ & $27.9(21.1-51.5)$ & $79.7(63.8-95.5)$ \\
\hline Al Shuwak & 160 & $95.6(94.4-96.8)^{a b}$ & $31.0(26.2-35.9)$ & $55.2(50.3-60.1)$ \\
\hline Al Faw & 100 & $97.0(95.8-98.2)^{a}$ & $30.1(24.9-35.3)$ & $53.5(48.3-58.7)$ \\
\hline
\end{tabular}

Columns not connected by the same letter are significantly different at a level of $P<0.05$ (Tukey-Kramer HSD test). 
Table 2 Mean mortality of and $50 \%$ and $90 \%$ knockdown times (in minutes) (KDT 50 and KDT 90 ) of female Anopheles arabiensis in populations from eastern and central Sudan in response to DDT exposure.

\begin{tabular}{lllll}
\hline Population & No. & Mortalities \% $(\mathbf{9 5 \%} \mathbf{C l})$ & KDT $_{\mathbf{5 0}}(\mathbf{9 5} \% \mathbf{C l})$ & KDT $_{\mathbf{9 0}} \mathbf{( 9 5 \% ~ C l )}$ \\
\hline Sennar & 320 & $39.7(19.8-59.53)^{\mathrm{b}}$ & $42.3(22.5-62.2)$ & $77.1(25.89-128.3)$ \\
Mayirno & 110 & $49.0(47.8-50.18)^{\mathrm{ab}}$ & $62.8(43.5-82.2)$ & $97.8(78.4-117.1)$ \\
Damazin & 300 & $39.0(19.1-58.86)^{\mathrm{b}}$ & $45.7(34.5-70.0)$ & $79.5(71.2-93.1)$ \\
Khartoum & 200 & $94.5(93.3-95.68)^{\mathrm{a}}$ & $30.4(26.8-33.8)$ & $53.9(47.2-65.7)$ \\
Kosti & 300 & $73.3(53.5-93.2)^{\mathrm{ab}}$ & $73.8(70.3-77.3)$ & $102.7(32.8-172.7)$ \\
Al Shuwak & 140 & $67.1(66.0-68.32)^{\mathrm{ab}}$ & $60.4(35.5-85.3)$ & $98.2(73.8-123.1)$ \\
\hline
\end{tabular}

Columns not connected by the same letter are significantly different at a level of $P<0.05$ (Tukey-Kramer HSD test).

result of past use in vector control. Other previous studies also showed that the selection of resistance to DDT in populations of malaria vectors was due to the longstanding and extensive use of DDT in the IRS programmes $[24,25]$. Interestingly the $\mathrm{kdr}$ genotype did not correlate well with resistance to DDT with over $43 \%$ the survivors being wild type for the $\mathrm{kdr}$ allele. This suggests that alternative resistance mechanisms are responsible for the DDT resistance.

Permethrin resistance is now well established in central Sudan with populations of An. arabiensis from three states (White Nile, Sennar and Blue Nile) showing less than $80 \%$ mortality to permethrin. The frequency of resistance appears to have increased considerably over the past three years as an earlier study in Sennar State found only one of four populations to be resistant to permethrin and none to DDT [10]. In contrast to DDT, permethrin resistance correlates with the presence of the 1014F genotype. However, this association between the presence of $\mathrm{kdr}$ and susceptibility/resistance to permethrin could be attributed mainly to the significant presence of the wild-type (Leu Leu) genotype among the dead individuals against the discriminated dose of this insecticide (Table 4). This suggests that this genotype is more likely to associate with susceptible phenotype than resistance in the mosquito vector $A n$. arabiensis from Sudan.

Overall, it is interesting to note that the association between the presence of $\mathrm{kdr}$ and resistance phenotype was weak for permethrin and absent for DDT, indicating that $\mathrm{kdr}$ is a dubious marker of both resistance to these insecticides and to be evidence for control failure in the populations tested of An. arabiensis. This association was shown quite strong in the closely related malaria

Table 3 Summary of 1014F kdr allele in alive and dead mosquitoes of An. arabiensis exposed to permethrin and DDT among six populations from eastern and central Sudan.

\begin{tabular}{|c|c|c|c|c|c|c|c|c|}
\hline \multirow[t]{2}{*}{ Origin } & \multirow[b]{2}{*}{ Insecticide } & \multirow[b]{2}{*}{ Phenotype } & \multicolumn{4}{|c|}{ kdr genotype } & \multicolumn{2}{|c|}{ Frequency } \\
\hline & & & Leu Leu & Leu Phe & Phe Phe & Total & $S$ & $\mathbf{R}$ \\
\hline \multirow[t]{4}{*}{ Mayirno } & DDT & Dead & 10 & 4 & 4 & 18 & 0.67 & 0.33 \\
\hline & & Alive & 27 & 0 & 1 & 28 & 0.96 & 0.04 \\
\hline & Permethrin & Dead & 5 & 3 & 0 & 8 & 0.81 & 0.19 \\
\hline & & Alive & 7 & 0 & 0 & 7 & 1.00 & 0.00 \\
\hline \multirow[t]{4}{*}{ Sennar } & DDT & Dead & 6 & 1 & 0 & 7 & 0.93 & 0.07 \\
\hline & & Alive & 8 & 13 & 4 & 25 & 0.58 & 0.42 \\
\hline & Permethrin & Dead & 7 & 0 & 0 & 7 & 1.00 & 0.00 \\
\hline & & Alive & 2 & 12 & 9 & 23 & 0.35 & 0.65 \\
\hline \multirow[t]{4}{*}{ Kosti } & DDT & Dead & 0 & 4 & 11 & 15 & 0.13 & 0.87 \\
\hline & & Alive & 0 & 0 & 15 & 15 & 0.00 & 1.00 \\
\hline & Permethrin & Dead & 0 & 7 & 17 & 24 & 0.15 & 0.85 \\
\hline & & Alive & 0 & 4 & 20 & 24 & 0.08 & 0.92 \\
\hline \multirow[t]{2}{*}{ Damazin } & DDT & Dead & 3 & 16 & 0 & 19 & 0.58 & 0.42 \\
\hline & & Alive & 4 & 8 & 8 & 20 & 0.40 & 0.60 \\
\hline \multirow[t]{3}{*}{ Al Shuwak* } & DDT & Dead & 1 & 0 & 0 & 1 & 1.00 & 0.00 \\
\hline & & Alive & 0 & 0 & 1 & 1 & 0.00 & 1.00 \\
\hline & Permethrin & Dead & 2 & 2 & 0 & 4 & 0.75 & 0.25 \\
\hline \multirow[t]{2}{*}{ Khartoum* } & DDT & Alive & 0 & 1 & 0 & 1 & 0.50 & 0.50 \\
\hline & Permethrin & Dead & 1 & 0 & 0 & 1 & 1.00 & 0.00 \\
\hline
\end{tabular}


Table 4 Frequency of $1014 \mathrm{~F} \mathrm{kdr}$ allele in survival and dead mosquitoes of An. arabiensis exposed to a WHO discriminating dose of permethrin and DDT.

\begin{tabular}{cccccc}
\hline Insecticide & Phenotype & No. tested & Leu Leu & Leu Phe & Phe Phe \\
\hline Permethrin & Dead & 44 & $0.34(15)$ & $0.27(12)$ & $0.39(17)$ \\
& Alive & 54 & $0.17(9)$ & $0.30(16)$ & $0.54(29)$ \\
& $P$ value & & 0.0460 & 0.7971 & 0.1361 \\
\multirow{4}{*}{ DDT } & Dead & 60 & $0.33(20)$ & $0.42(25)$ & $0.25(15)$ \\
& Alive & 90 & $0.43(39)$ & $0.24(22)$ & $0.32(29)$ \\
& $P$ value & & 0.2174 & 0.0267 & 0.3384 \\
\hline
\end{tabular}

vector Anopheles gambiae and it emphasized that $\mathrm{kdr}$ genotype might explain only a portion of heritable variation in resistance phenotype and that diagnostic assays to test the importance of other resistance mechanisms in field populations are required [26-28]. This could be further supported by the fact that, in the present study, approximately $16.7 \%$ of the survivors An. arabienis against permethrin were $\mathrm{kdr}$ negative indicating a role for additional pyrethroid resistance mechanisms.

The $1014 \mathrm{~S}$ mutation was not detected in the six populations screened. The $1014 \mathrm{~S}$ mutation has previously been observed in one out of three populations in Kassala state [9] but absent in Gezira and Sennar [10]. The result suggests limited distribution of $1014 \mathrm{~S}$ allele which so far reported only from Kassala town.

\section{Conclusion}

The observed co-resistance to permethrin coupled with the occurrence of high resistance to DDT and high $\mathrm{kdr}$ frequency in populations of An. arabiensis could greatly affect the malaria vector control in Sudan. Relying on the use of ITNs alone may not continue to provide adequate control if this trend continues. Thus, the national malaria control program may need to consider additional methods for malaria vector control in Sudan.

\section{Acknowledgements}

We thank Ahmed Omer, Hyder Abd Allah and Nazar Abdel EL Galeel for technical assistance during mosquito collections and bioassays and Toe Kobie Hyacinth, Antoine Sanou and Safa Ahmed for help with the genotyping. We also thank professor Muntaser Ibrahim from Institute of Endemic Diseases (IEND), University of Khartoum and Dr. George Skavdis, Agricultural University of Athens, Athens, Greece, for hosting and advising in doing this research at IEND before to be done at LSTM in UK. This work is supported by a small grant scheme from EMRO, WHO/TDR (Project ID SGS08/120) to Y.E. Himeidan.

\section{Author details}

${ }^{1}$ Entomology Unit, Faculty of Agriculture and Natural Resources, University of Kassala, New Halfa, Sudan. ${ }^{2}$ Institute of Endemic Diseases (IEND), University of Khartoum. ${ }^{3}$ Vector Group, Liverpool School of Tropical Medicine, Pembroke Place, Liverpool, UK, L3 5QA.

\section{Authors' contributions}

YEH supervised field work, performed data management and statistical analyses, provide results interpretation and drafted the manuscript, CMJ and MMA carried out the laboratory analyses, HR supervised the laboratory work, drafted and critically reviewed and finalized this paper for publication. All authors read and approved the final manuscript.

\section{Competing interests}

The authors declare that they have no competing interests.

Received: 5 July 2011 Accepted: 3 August 2011

Published: 3 August 2011

References

1. Tatem AJ, Smith DL, Gething PW, Kabaria CW, Snow RW, Hay SI: Ranking of elimination feasibility between malaria-endemic countries. Lancet 2010, 376:1579-1591.

2. World Malaria Report 2010: Executive summary and key points.[http:// www.who.int/malaria/world_malaria_report_2010/ malaria2010_summary_keypoints_en.pdf].

3. Ranson H, N'Guessan R, Lines J, Moiroux N, Nkuni Z, Corbel V: Pyrethroid resistance in African anopheline mosquitoes: what are the implications for malaria control? Trends Parasitol 2011, 27:91-8.

4. Martinez-Torres D, Chandre F, Williamson MS, Darriet F, Bergé JB, Devonshire AL, Guillet P, Pasteur N, Pauron D: Molecular characterization of pyrethroid knockdown resistance $(\mathrm{kdr})$ in the major malaria vector Anopheles gambiae s.s. Insect Mol Biol 1998, 7:179-84.

5. Ranson $H$, Jensen B, Vulule JM, Wang X, Hemingway J, Collins FH: Identification of a point mutation in the voltage-gated sodium channel gene of Kenyan Anopheles gambiae associated with resistance to DDT and pyrethroids. Insect Mol Biol 2000, 9:491-7.

6. Diabate A, Brengues $C$, Baldet T, Dabiré KR, Hougard JM, Akogbeto M Kengne P, Simard F, Guillet P, Hemingway J, Chandre F: The spread of the Leu-Phe kdr mutation through Anopheles gambiae complex in Burkina Faso: genetic introgression and de novo phenomena. Trop Med Int Health 2004, 9:1267-1273.

7. Dabire KR, Diabate A, Namountougou M, Toe KH, Ouari A, Kengne P, Bass C, Baldet T: Distribution of pyrethroid and DDT resistance and the L1014F kdr mutation in Anopheles gambiae s.l. from Burkina Faso (West Africa). Trans R Soc Trop Med Hyg 2009, 103:1113-1120.

8. Kulkarni MA, Rowland M, Alifrangis M, Mosha FW, Matowo J, Malima R, Peter J, Kweka E, Lyimo I, Magesa S, Salanti A, Rau ME, Drakeley C: Occurrence of the leucine-to-phenylalanine knockdown resistance $(\mathrm{kdr})$ mutation in Anopheles arabiensis populations in Tanzania, detected by a simplified high-throughput SSOP-ELISA method. Malar J 2006, 5:56.

9. Himeidan YE, Chen H, Chandre F, Donnelly MJ, Yan G: Short report: permethrin and DDT resistance in the malaria vector Anopheles arabiensis from eastern Sudan. Am J Trop Med Hyg 2007, 77:1066-1068,

10. Abdalla H, Matambo TS, Koekemoer LL, Mnzava AP, Hunt RH, Coetzee M: Insecticide susceptibility and vector status of natural populations of Anopheles arabiensis from Sudan. Trans R Soc Trop Med Hyg 2008, 102:263-271.

11. Pagès F, Texier G, Pradines B, Gadiaga L, Machault V, Jarjaval F, Penhoat $K$, Berger F, Trape JF, Rogier C, Sokhna C: Malaria transmission in Dakar: a two-year survey. Malar J 2008, 7:178.

12. Yewhalaw D, Bortel WW, Denis $L$, Coosemans M, Duchateau $L$, Speybroeck N: First evidence of high knockdown resistance frequency in Anopheles arabiensis (Diptera: Culicidae) from Ethiopia. Am J Trop Med Hyg 2010, 83:122-125.

13. Balkew M, Ibrahim M, Koekemoer LL, Brooke BD, Engers H, Aseffa A, GebreMichael T, Elhassen I: Insecticide resistance in Anopheles arabiensis (Diptera: Culicidae) from villages in central, northern and south west Ethiopia and detection of kdr mutation. Parasit Vectors 2010, 3:40.

14. Verhaeghen K, Van Bortel W, Trung HD, Sochantha T, Keokenchanh K: Knockdown resistance in Anopheles vagus, An. sinensis, An. paraliae and An. peditaeniatus populations of the Mekong region. Parasit Vectors 2010, 3:59.

15. Stump AD, Atieli FK, Vulule JM, Besansky NJ: Dynamics of the pyrethroid knockdown resistance allele in western Kenyan populations of Anopheles gambiae in response to insecticide-treated bed net trials. Am J Trop Med Hyg 2004, 70:591-596.

16. Chen H, Githeko AK, Githure Jl, Mutunga J, Zhou G, Yan G: Monooxygenase levels and knockdown resistance $(\mathrm{kdr})$ allele frequencies in Anopheles gambiae and Anopheles arabiensis in Kenya. J Med Entomol 2008, 45:242-50. 
17. Ndjemai HN, Patchoke S, Atangana J, Etang J, Simard F, Bilong CF, Reimer L, Cornel A, Lanzaro GC, Fondjo E: The distribution of insecticide resistance in Anopheles gambiae s.l. populations from Cameroon: an update. Trans R Soc Trop Med Hyg 2009, 103:1127-1138.

18. Gillies MT, Coetzee M: A supplement to the Anophelinae of Africa South of the Sahara (Afrotropical Region) (publication no. 55) Johannesburg: South Africa Institute for Medical Research; 1987.

19. Petrarca V, Nugud AD, Ahmed MA, Haridi AM, Di Deco MA, Coluzzi M: Cytogenetics of the Anopheles gambiae complex in Sudan, with special reference to An. arabiensis: relationships with East and West African populations. Med Vet Entomol 2000, 14:149-164.

20. Himeidan YE, Elzaki MM, Kweka EJ, Ibrahim M, Elhassan IM: Pattern of malaria transmission along the Rahad River basin, eastern Sudan. Parasit Vectors 2011, 4:109.

21. World Health Organization, 1998: Tests Procedures for Insecticide Resistance Monitoring in Malaria Vectors, Bio-Efficacy and Persistence of Insecticides on Treated Surfaces. Report of the WHO Informal Consultation. Geneva: World Health Organization.

22. Livak KJ: Organization and mapping of a sequence on the Drosophila melanogaster $\mathrm{X}$ and $\mathrm{Y}$ chromosomes that is transcribed during spermatogenesis. Genetics 1984, 107:611-634.

23. Bass C, Nikou D, Donnelly MJ, Williamson MS, Ranson H, Ball A, Vontas J, Field LM: Detection of knockdown resistance $(\mathrm{kdr})$ mutations in Anopheles gambiae: a comparison of two new high-throughput assays with existing methods. Malar J 2007, 6:111.

24. Lines JD: Do agricultural insecticides select for insecticide resistance in mosquitoes? A look at the evidence. Parasitol Today 1988, 4:S17-20.

25. Protopopoff N, Verhaeghen K, Van Bortel W, Roelants P, Marcotty T, Baza D, D'Alessandro U, Coosemans M: A significant increase in kdr in Anopheles gambiae is associated with an intensive vector control intervention in Burundi highlands. Trop Med Int Health 2008, 13:1479-1487.

26. Brooke BD, Koekemoer LL: Major effect genes or loose confederations? The development of insecticide resistance in the malaria vector Anopheles gambiae. Parasit Vectors 2010, 3:74.

27. Lynd A, Weetman D, Barbosa S, Egyir Yawson A, Mitchell S, Pinto J, Hastings I, Donnelly MJ: Field, genetic, and modeling approaches show strong positive selection acting upon an insecticide resistance mutation in Anopheles gambiae s.s. Mol Biol Evol 2010, 27:1117-25.

28. Donnelly MJ, Corbel V, Weetman D, Wilding CS, Williamson MS, Black WC: Does kdr genotype predict insecticide-resistance phenotype in mosquitoes? Trends Parasitol 2009, 25:213-9.

doi:10.1186/1756-3305-4-154

Cite this article as: Himeidan et al.: Extensive permethrin and DDT resistance in Anopheles arabiensis from eastern and central Sudan. Parasites \& Vectors 2011 4:154.

\section{Submit your next manuscript to BioMed Central and take full advantage of:}

- Convenient online submission

- Thorough peer review

- No space constraints or color figure charges

- Immediate publication on acceptance

- Inclusion in PubMed, CAS, Scopus and Google Scholar

- Research which is freely available for redistribution

Submit your manuscript at www.biomedcentral.com/submit
C Biomed Central 